\title{
Soft Skills by Engineering Employers
}

\author{
Débora Barni de Campos ${ }^{1 *}$, Luis Mauricio Martins Resende ${ }^{2}$, Alexandre Borges Fagundes ${ }^{1}$ \\ ${ }^{1}$ Departamento de Tecnologia Industrial, Centro de Educação do Planalto Norte, Universidade do Estado de Santa Catarina, \\ São Bento do Sul, Brasil \\ ${ }^{2}$ Departamento de Engenharia de Produção, Campus de Ponta Grossa, Universidade Tecnológica Federal do Paraná, \\ Ponta Grossa, Brasil \\ Email: *deborabarni@gmail.com
}

How to cite this paper: de Campos, D. B., Resende, L. M. M., \& Fagundes, A. B. (2020). Soft Skills by Engineering Employers. Creative Education, 11, 2133-2152. https://doi.org/10.4236/ce.2020.1110155

Received: September 3, 2020

Accepted: October 24, 2020

Published: October 27, 2020

Copyright (c) 2020 by author(s) and Scientific Research Publishing Inc. This work is licensed under the Creative Commons Attribution International License (CC BY 4.0).

http://creativecommons.org/licenses/by/4.0/ (cc) (i) Open Access

\begin{abstract}
The aim of this study was to understand and compare the expectation and perception of 40 engineering employers regarding the soft skills in Engineers. The most important soft skills for an Engineering professional, identified through a systematic bibliographic review, were arranged into six groups, as follows: critical thinking, creative thinking, communication, teamwork, ethical perspective and emotional intelligence. The chosen methodology for data analysis was a fuzzy logic, in order to preserve the subjectivity inherent to soft skill. Forty psychologists were also interviewed and the delphi method was used to include their perceptions between soft skills for calibration of the fuzzyTECH software. The results obtained with the fuzzyfication of the data revealed that the perception of employers of soft skills in engineering professionals is not inline to their expectations in the scenario they are inserted.
\end{abstract}

\section{Keywords}

Soft Skills, Engineering Employers, Job Market

\section{Introduction}

Engineering is usually associated with technical skills, logics and mathematics. In the present study, the objective was to investigate the importance and necessity of the soft skills, taking the engineering field employers perception as a starting point.

Engineering professionals have a broad range of workplace possibilities, from entrepreneurship to non-governmental entities, including people management, education, academic research, hospitals and public institutions. They can perform their tasks in an individual manner as well as in big interdisciplinary teams (Diálogos Setoriais, 2017). 
According to the same study, this broad range of performance possibilities for Engineering is a result of the multiple skills expected from these professionals, acquired both during Academia and during the work experiences.

To Itani \& Srour (2015), the high demand for non-technical skills is already a reality, allowing the exchange between social knowledge and Engineering. The same authors also point out a gap in the development of the soft skills, essential and extremely requested by engineering employers.

In the same way that the complexity in the performance of these professionals is presented through its diverse scope, the expectation with relation to their performance is also complex. It is known that training and professional development in Engineering, as for all other areas, takes place both through one's academic and life experiences (Campos, 2019).

The Engineering employers certainly evaluate the technical skills of the candidates, but what truly sustains a candidate in their position in long term are their ability to communicate and to interact with others in the most diverse spheres, the so-called soft skills (Swiatkiewicz, 2014). These are referred by OCDE 2015 as soft skills, which are said to be indispensable for human relationships, and englobe ethics, emotional intelligence, communication and creativity.

Nowadays, these soft skills govern business management models, being essential requirements for hiring, evaluating and keeping positions in companies around the world, as they relate to the ability to fulfill a certain function, going beyond technical knowledge and market experience (OECD, 2016; Pellegrini, 2017).

According to Börner et al. 2018, there is a gap between the soft skill needs in the technical fields and in the number of graduate professionals which truly have them, making them even more required for these positions.

Considering the current market's needs, the aim of this paper is to compare the expectations and the reality experienced by the Engineering employers with regards to the soft skills.

\section{Justification}

The job market has been addressing the need for professional Engineers with a broader profile, including skills that transcend technical ones.

According to Schipper \& Stappen (2018), the demands for Engineering graduates require that they not only act according to high technical standards, but also have a set of soft skills to increase their employability. Still according to the authors, the development of soft skills is a must in Engineers training.

The need for broader training has already shown a direct impact on market demands (El Mansour \& Dean, 2016; Ramadi, Ramadi, \& Nasr, 2015). In an attempt to instigate Brazilian educational institutions, the National Confederation of Industries of Brazil (CNI), in conjunction with the Brazilian Engineering Education Association of Brazil (ABENGE), prepared a proposal-in January 2018-for National Curricular Guidelines (DCN) for Brazilian Engineering courses, based on skills development, with an emphasis on the soft skills (Abenge, 2018). 
The authors of this research, as Engineering courses professors, note that many of the decisions made in the construction of pedagogical projects are elaborated empirically or punctually, without a more careful analysis of the curricular proposal. This is probably due to the complexity of the different areas that cover socio-emotional competences.

In the preparation of pedagogical projects, it is not common to use scientific instruments that take into account socio-emotional skills for the training of Engineers. Most decisions do not include the perception of graduates and employers in the formation of the desired professional.

There are few instruments to assist in decision-making, other than assessing social skills to measure the desire of the labor market, correlating with reality, forming an important bridge between academia and the professional practice of the Engineers. In this sense, the present research offers a scientific instrument to fulfill this gap, allowing, that, in the event of pedagogical projects elaboration, that the perceptions of Engineering contractors is considered. Besides, it also reveals what is found in the job market regarding soft skills. The results collected can help university managers to take better decisions regarding the development of these skills.

\section{Theoretical Reference}

\subsection{Soft Skills and Their Relevance for Engineers}

In the professional experience context, competencies are defined as a dynamic combination of the professional's knowledge, skills and attitudes under a given organizational strategy or context (Carbone et al., 2005; Freitas \& Brandão, 2005). Considering that Engineers work in different fields, such as project management and development, mostly inside a multidisciplinary team, soft skills are the bridge between different areas of knowledge.

The development of soft skills should also be considered as part of the Engineers' training, as well as of any other professional, as they are equally or more necessary than the technical skills to allow these professionals to perform according to the current demands.

For Rios-Carmenado et al. (2015), there is a gap between the soft skills in an Engineering training and what is expected from these professionals, emphasizing a need for the development of these skills.

In relation to the insertion of the Engineering professionals in the market, Laranjeiro et al. (2020), identify that job descriptions for Engineering mostly require soft skills, making them essential through all the steps of the entire selective process.

In view of this reality, which highlights the importance of the soft skills, it is essential to investigate which ones play a decisive role in the hiring and retention of engineers in their positions.

Campos (2019), one of the authors of the present paper, performed an extensive bibliographic review, which outlined the important soft skills for Engineers, 
as described in the following paragraphs.

Critical thinking, which, according to Paul \& Elder (2020), is the ability to conduct a structured thinking process to analyze and evaluate a given situation with the aim of improving it. For Campos (2019), this skill includes problem solving and open mind. For the same author, "Communication" includes oral and written communication, active listening, reading and foreign language.

Team Work, which according to Nascimento (2019), represents the dynamic collaboration of a group towards a common goal. For Campos (2019), it includes multiculturalism, networking and leadership.

Ethical Perspective, which, according to Boff (2017), permeates all the spheres of human existence. For Campos (2019), it includes social responsibility and professionalism.

Emotional Intelligence, which, for Serrat (2017), refers to the recognition, evaluation and management of one's own and others emotions. For Campos (2019), it includes motivation, self-direction, lifelong learning and control of emotions.

For Hasanah \& Surya (2017), creative thinking is the ability of creating something new, which can be achieved through the proposal of innovative ideas, connecting causalities between existing ideas and processes and orienting to problem-solving. For Campos (2019), it includes creativity and innovation.

\subsection{The Engineering Employer Profile}

Considering that employers deal more directly with people and business management, their responsibilities and tasks require more explicitly to have soft skills, such as leadership and flexibility.

According to Reh (2020), the skills linked to the employer's profile in the Engineering field are directly related to leadership, communication, critical thinking and team work, evidencing the soft skills as key needs for development in the job market.

For Tibério \& Tonini (2013), difficulties are encountered when transitioning for a purely Engineering position to management, and the development of the necessary skills for management is essential to turn this transitioning smoother. The need to transition for management happens in the context of a capitalist model that requires more flexibility and adaptation to search for results, which largely depend on a manager's relationship with their team.

Therefore, it is clear that some competencies (technical and mainly soft skills) are already present in leadership and management positions in the Engineering area. The presence of these characteristics is directly correlated to insertion and especially professional development in the area of engineering.

\subsection{Fuzzy Logic}

The present research measured characteristics of soft skills, inherently influenced by the subjective, uncertain and imprecise character of the thought and 
behavior. To treat the data, the use of fuzzy logic was chosen as it allows to calculate the intrinsic subjectivities in the numerical responses, taking into account not only the outliers, but also some intermediaries values that escape the usual mathematical data treatment of Aristotelian logic.

For Belohlávek et al. (2017), logic started in Ancient Greece, with Aristotle and later with Epicurus, through to the classic logic based on bivalence. This line of thought works with solid components, with the certainty of things and exact answers, contributing to much of the bivalent mathematics known today.

The Fuzzy Logic, on the other hand, encompasses numerical uncertainties for its resolutions. It includes and makes values diffuse so that data can exist in different groups simultaneously, in an attempt to mimic and approach human reasoning, which processes different information at the same time and still allows the elaboration of both concrete and subjective data (Belohlávek et al., 2017).

The proportions of a certain characteristic can be cited as an example. In the Binary Logic, right and wrong are taken as basic values, one or two, exact values. In the Fuzzy Logic, however, there is a less concrete scope in the accuracy of the results and mathematical questions, such as: cold or hot, neither so cold nor so hot. There is no exact value of right and wrong, but subjective and malleable reasoning (to some extent).

In this fuzzy logic, one can consider subjective values, qualitative and quantitative content, which, transformed into data, do not lose their reality and generalist character, making the logical reasoning of the study closer to the conceptual and numerical reality to be studied.

\section{Materials and Methods}

The development of this applied research utilized the soft skills deriving from a Bibliographic Review conducted by one of the present study's authors in her research work from 2015 e 2019 (Campos, 2019). After the analysis of 3.951 articles, the study highlighted 19 soft skills for Engineers, classified into six main categories, presented following.

Communication: Oral and Written Communication, Active Listening, Reading and Foreign Language; Critical Thinking: Problem Solving, Open Mind and Critical Thinking per si; Creative Thinking: Creativity and Innovation; Emotional Intelligence: Control of emotions, Lifelong Learning, Motivation and Self-Direction; Ethics: Ethics per si, Professionalism and Social Responsibility; and Team Work: Multiculturalism, Leadership and Networking.

In order to obtain a real scenario about the employers' opinion on the soft skills of Engineers, the impressions of 40 Engineers employers who are manager at least one Engineer were collected. This was conducted through semi-structured interviews (Table 1), and the respondents answered the same questionnaire twice, considering two different circumstances: expectations at the time of hiring and the reality observed among their Engineering collaborators.

This study was approved by the Ethics Committee on Research with Human 
Table 1. Structured interview.

Consider that, to hire an Engineer in your organization, soft skills are evaluated using this query. Mark, for each of these skills, according to the corresponding scale, the minimum expected for a potential candidate to be able to be part of your organization.

Questions about Problem Solving

D1-Find solutions using multidisciplinary knowledge

D2-Use knowledge, data and facts to solve problems at work

$\begin{array}{lllllllllll}0 & 1 & 2 & 3 & 4 & 5 & 6 & 7 & 8 & 9 & 10\end{array}$

Questions about Open Mind

D3-Ability to solve problems in a pacific manner

D4-Openness to suggestions, new ideas and contrary opinions

$\begin{array}{lllllllllll}0 & 1 & 2 & 3 & 4 & 5 & 6 & 7 & 8 & 9 & 10\end{array}$

Questions about Verbal Communication

D5-Ability to talk in public

D6-Ability to present ideas clearly during a conversation

\section{Questions about Written Communication}

D7-Ability to write complex reports and documents with clarity

D8-Having an understandable handwriting and good domain

of grammar and rules of the native language

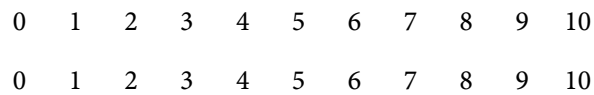

Questions about Active Listening

D9-Ability to listen the interlocutor and wait to speak

D10-Think in an articulate manner, with clear and efficient ideas

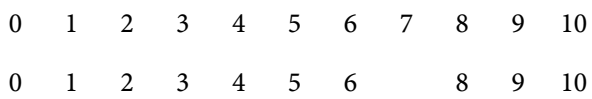

$\begin{array}{lllllllllll}0 & 1 & 2 & 3 & 4 & 5 & 6 & 7 & 8 & 9 & 10\end{array}$

$\begin{array}{lllllllllll}0 & 1 & 2 & 3 & 4 & 5 & 6 & 7 & 8 & 9 & 10\end{array}$

Question about Reading

D11-Ability to interpret complex texts, being able to utilize all the data contained in them

$\begin{array}{lllllllllll}0 & 1 & 2 & 3 & 4 & 5 & 6 & 7 & 8 & 9 & 10\end{array}$

$\begin{array}{lllllllllll}0 & 1 & 2 & 3 & 4 & 5 & 6 & 7 & 8 & 9 & 10\end{array}$

Question about Foreign Language

D12-Ability to read, speak and write in a language other than the native language

$\begin{array}{lllllllllll}0 & 1 & 2 & 3 & 4 & 5 & 6 & 7 & 8 & 9 & 10\end{array}$

\section{Question about Multiculturalism}

D13-Ability to work in collaboration with individuals from different cultures, genders, religions and lifestyles

\section{Question about Networking}

D14-Creation of collaborative relationships with colleagues and clients

\section{Questions about Leadership}

D15-Ability to negotiate and manage conflicts with diverse teams

D16-Encourage others to develop their strengths to achieve a common goal

D17-Ability to use interpersonal skills to train and develop others

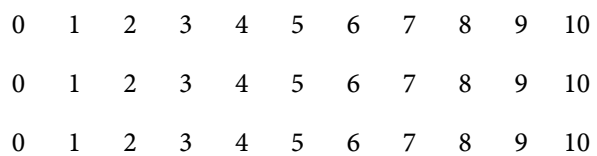

Question about Ethics

D18-Demonstrate Integrity and ethical behavior

$\begin{array}{lllllllllll}0 & 1 & 2 & 3 & 4 & 5 & 6 & 7 & 8 & 9 & 10\end{array}$

Question about Professionalism

D19-Commitment with work

$\begin{array}{lllllllllll}0 & 1 & 2 & 3 & 4 & 5 & 6 & 7 & 8 & 9 & 10\end{array}$

Question about Social Responsibility

20-Act responsibly according to the society's needs

$\begin{array}{lllllllllll}0 & 1 & 2 & 3 & 4 & 5 & 6 & 7 & 8 & 9 & 10\end{array}$

Questions about Control of Emotions 


\section{Continued}

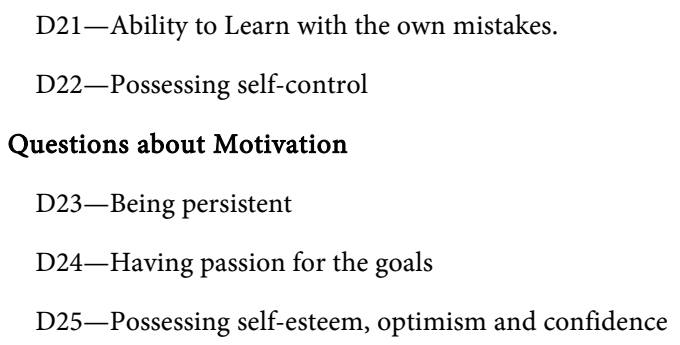

Beings (CEPSH) of UTFPR, in Curitiba/PR, on 06/05/2019, under the number $3,371,131$. The following text approves the document: "There are no pending issues. The protocol presented in this third version complies with the provisions of Resolution 466/2012. Status: Approved “.

The participants of this study, who agreed to answer the structured questionnaire consisting of 29 questions, consisted of Engineering employers who manage at least one Engineering professional. The selection of this group comprises a non-probabilistic sampling of the type "for" convenience, which according to Gil (2002), is the one in which the research universe does not need to be completely defined for the research to be carried out.

The structured interviews were conducted online using the free Google Forms platform. The participants gave a score from 0 to 10 regarding the expectations about the minimum level of soft skills that an Engineer would need in order to be hired in their organization as well as their perception of the reality of soft skills of the Engineers already working on their teams. These notes were grouped by means of average and inserted in the fuzzyTECH program, composing a diagnosis about the perceptions of this set.

A questionnaire considering soft skills was also developed, and it was answered by 40 psychologists, supporting the quantitative treatment carried out in this study. The choice for this group of professionals was based on their relation with human behavior study.

In order to increase the reliability of the answers, the Delphi method was used as a complementary methodology. As Fagundes 2015 explains, this association of the Delphi method with a Likert scale tends to converge the data and reduce the dispersion of responses. The Delphi method aims to bring responses to a collec- 
tive consensus of ideas, thus demonstrating the most representative value rather than isolate opinions. The trends of leading opinions may come to prevail over all other opinions and thus interfere with the group's results (Giovinazzo, 2001).

For the scientific legitimacy of this process in the Delphi method, three criteria were obeyed: the anonymous identity of the respondents, the statistical representation of the values distribution and the return of the group's responses to the new evaluation in the flowing rounds (Listone \& Turoff, 2002, Wright et al. 2000, Martino 1993).

In the second and last round, the same questionnaire as in the first round was used for the same interviewees. They have the Weighted Average of the result of the first stage obtained by all the respondent specialists, as well as the data previously measured by themselves. In this way, the experts decided whether they would like to keep or change their answers of the first round, increasing the reliability of the answers. In case of modification of answers, there is a decrease in the dispersion of the values (Fagundes 2015).

Table 2 shows the final average of the values attributed by psychologists after applying the Delphi method to each of the questions, evaluating the influence of each soft skills on others.

This group of professionals was used to calibrate the fuzzyTECH software, by weighing the influence between each soft skill on the other.

The fuzzyTECH software was elected to build the model, in order to compare the expectation and the reality perceived by the Engineering employers. This software has a friendly interface, in addition to not requiring knowledge about programming and having a worldwide support in the field of fuzzy logic and because the authors of this study acquired the version 5.54 license. The structured model was designed by one of the authors of this study (Campos, 2019), and has the shape of a top-down tree, shown in Figure 1.

The participation of employers, through questionnaires, provided answers that served as input data for fuzzyTECH.

The construction of the top-down tree was based on the result to be discovered and has 4 hierarchical levels (Figure 2).

The fourth level, which represents the Final Result (employers' expectations

Table 2. Average of the values assigned by psychologists, after application of the Delphi method.

\begin{tabular}{|c|c|}
\hline Guideline/Index/Indicator & Average \\
\hline D1: How much "Find Solutions using multidisciplinary knowledge" using impacts "Problem Solving" & 8.51 \\
\hline D2: How much "Use knowledge, data and facts" impacts em "Resolução de Problemas" & 8.89 \\
\hline D3: How much "Ability to solve problems in a pacific manner" impacts "Open Mind" & 7.29 \\
\hline D4: How much "Openness to suggestions, new ideas and contrary opinions" impacts "Open Mind" & 9.46 \\
\hline D5: How much "Ability to talk in public" impacts "Oral Communication" & 8.17 \\
\hline D6: How much "Ability to present ideas clearly during a conversation" impacts "Oral Communication" & 9.17 \\
\hline
\end{tabular}




\section{Continued}

D7: How much "Ability to write complex reports and documents with clarity" impacts "Written Communication"

D8: How much "Possuir boa ortografia e conhecimento da língua culta de sua origem” impacts "Written Communication” 8.86

D9: How much "Ability to listen to the interlocutor and wait to speak" impacts "Active Listening"

D10: How much "Think in an articulate manner, with clear and efficient ideas" impacts "Active Listening” 8.46

D15: How much "Ability to negotiate and manage conflicts with diverse teams" impacts "Leadership" 9.140

D16: How much "Encourage others to develop their strengths to achieve a common goal" impacts "Leadership" 9.230

D17: How much "Ability to use interpersonal skills to train and develop others" impacts "Leadership" 9.06

D21: How much "Ability to learn with the own mistakes" impacts "Control of emotions" 7.97

D22: How much "Possessing self-control" impacts "Control of emotions" 9.09

D23: How much "Being persistent" impacts "Motivation” 8.34

D24: How much "Having passion for the goals" impacts "Motivation" 9.20

D25: How much "Possess self-esteem, optimism and confidence" impacts "Motivation" 9.20

ID1: How much "Problem Solving” impacts "Critical Thinking” 7.71

ID2: How much “Open Mind” impacts “Critical Thinking”

ID3: How much a "Orality" impacts "Communication" 8.66

ID4: How much a "Writing” impacts “Communication” 8.54

ID5: How much “Active Listening” impacts “Communication” 9.09

D11: How much "Reading" impacts "Communication" 8.63

D12: How much "Foreign Language" impacts “Communication” 7.43

D13: How much "Multiculturalism" impacts “Team Work” 8.20

D14: How much "Networking” impacts "Team Work” 7.51

ID10: How much "Leadership" impacts "Team Work” 8.33

ID18: How much "Personal Ethics" impacts "Ethic Perspective" 9.06

D19: How much que "Professionalism" impacts "Ethic Perspective" 9.14

D20: How much que "Social Responsibility" impacts "Ethic Perspective” 8.54

ID14: How much “Control of Emotions” impacts "Emotional Intelligence” 9.23

ID15: How much "Motivation" impacts "Emotional Intelligence" 8.14

D26: How much "Lifelong Learning” impacts “Emotional Intelligence” 8.51

D27: How much "Self-Direction" impacts "Emotional Intelligence” 8.17

D28: How much “Creativity” impacts “Creative Thinking” 9.29

D29: How much "Innovation” impacts “Creative Thinking” 9.17

IC1: How much "Critical Thinking” impacts the soft skills of an Engineer 8.89

IC2: How much “Communication” Impacts the soft skills of an Engineer

IC3: How much "Team Work" impacts the soft skills of an Engineer 8.49

IC4: How much "Ethical Perspective" impacts the soft skills of an Engineer 8.94

IC5: How much "Emotional Intelligence" impacts the soft skills of an Engineer 8.80

IC6: How much "Creative Thinking” impacts the soft skills of an Engineer.

Source: Campos, 2019. 

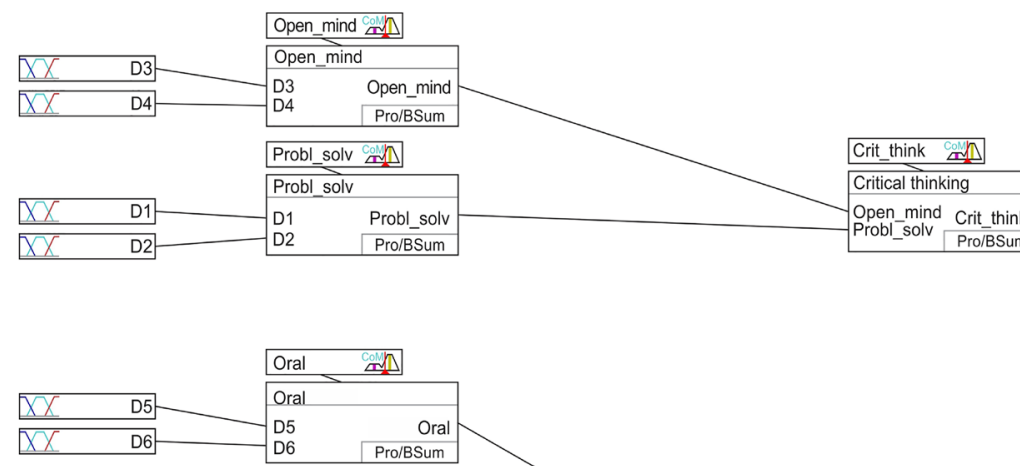

$$
\begin{array}{|lr|}
\hline \text { Oral } & \text { rayn } \\
\hline \text { Oral } & \\
\hline \text { D5 } & \\
\text { D6 } & \text { Oral } \\
& \text { Pro/BSum } \\
\hline
\end{array}
$$

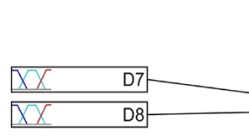

D6 19

\begin{tabular}{|c|c|c|c|}
\hline \multirow{2}{*}{\multicolumn{2}{|c|}{ 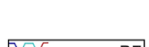 }} & \multicolumn{2}{|r|}{ (x) } \\
\hline & & & \\
\hline$\frac{\Delta \lambda}{\nabla X}$ & $\mathrm{D} 8$ & $D$ & Write \\
\hline
\end{tabular}
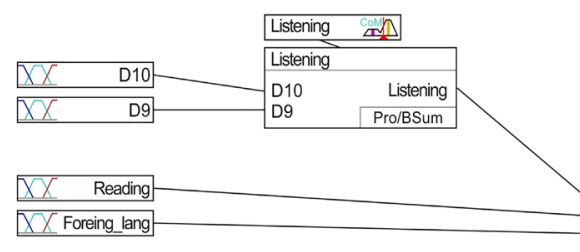

XX Foreing_lang

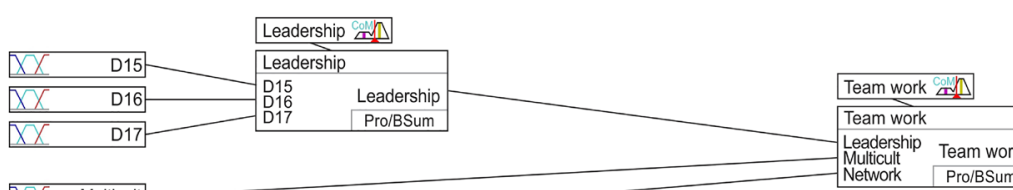

$X X \quad$ Multicult

XX Network

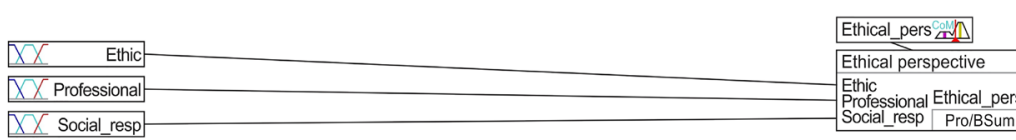

\section{Social_resp} \begin{tabular}{l|l} 
Ethic & Ethical_pers \\
Professional Ethial_resp & Pro/BSum \\
\hline
\end{tabular}

\begin{tabular}{|c|c|c|c|}
\hline & \multicolumn{2}{|c|}{ Cont_emot } \\
\hline & & \multicolumn{2}{|c|}{ Cont_emot } \\
\hline$x \bar{x}$ & D21 & D21 & Cont_emot \\
\hline & D22 & D22 & Pro/BSum \\
\hline
\end{tabular}

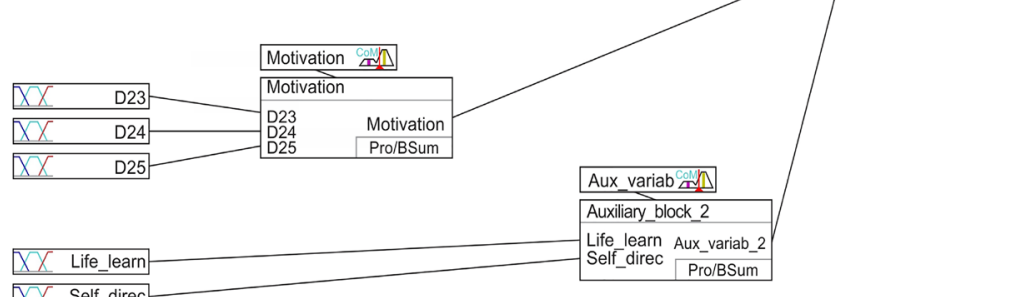

XX Self_direc

Life_learn Aux_variab_2
Self_direc

\begin{tabular}{ll}
\hline$X X$ & Creativity \\
\hline$X X$ & Innovation \\
\hline
\end{tabular}

Creat think coly

Source: Campos, 2019.

Figure 1. Top-down tree. 


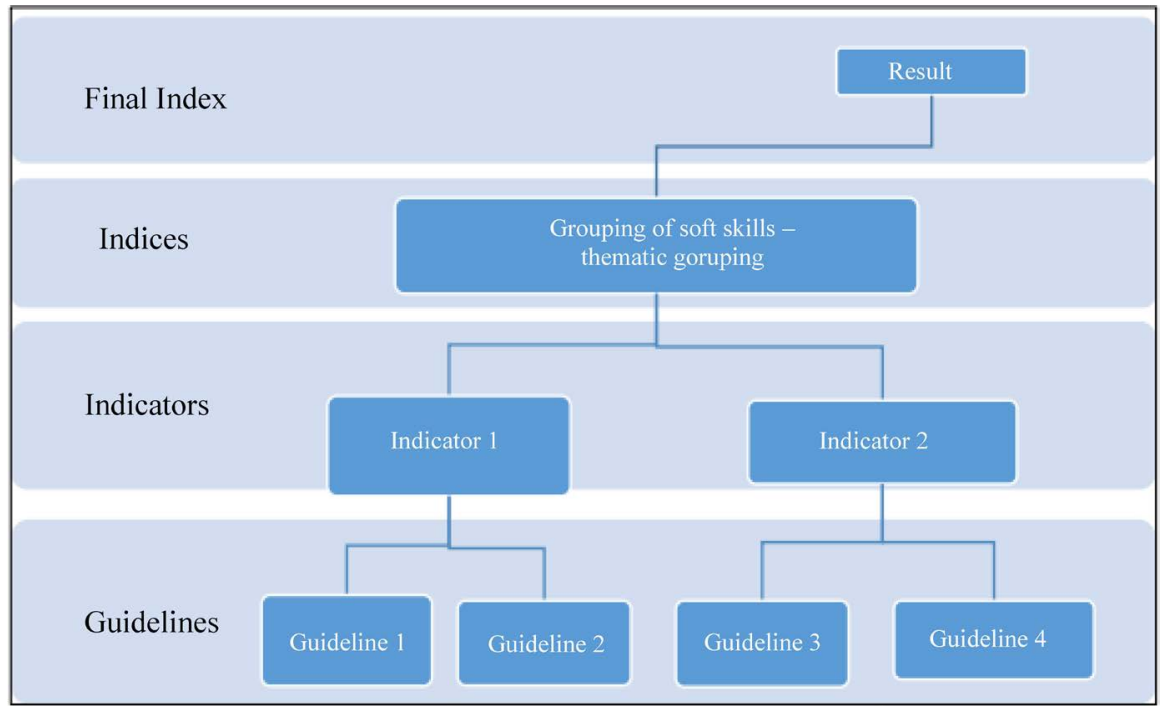

Source: Own authorship.

Figure 2. Simplified scheme of the proposed model.

and the real level of Engineers soft skills), was obtained through the aggregation of the indexes. On the other hand, the indices obtained from the aggregation of soft skills, from thematic groups (indicators), make up the third level. The indicators constitute the second level and are the soft skills obtained from the RBS bibliometry carried out by Campos, Resende, \& Fagundes (2020), broken down into guidelines inspired by the P21 report (Casner-Lotto, Barrington, 2006), which represent the first level, as well as the tree input data.

This hierarchy represents a simplified cut of the Model mounted on the fuzzyTECH tree, showing the logical sequence to reach the final result, which is the employers' perception of the expectations and the reality of the level of soft skills of the engineers.

When the values were treated using the fuzzy logic, they provided the status quo not only of the most relevant soft skills for Engineers based on the perception of this group of respondents, but also the expectation of the labor market on the importance of each of these competencies. The desire of the labor market, used as an ideal parameter, allowed the comparison with the reality of soft skills.

\section{Results and Discussion}

\subsection{About the Profile of Interviewed Employees}

The data of the 40 employers were obtained from the questionnaires, and a demographic profile was designed as a result. The profile, seen in Table 3, shows a majority with an Engineering background, operating predominantly in large companies.

As shown in Table 3, there is a prevalence of men, showing an outline of a general reality of Engineering, regarding gender and skills. According to Hong (2016), skills are based on biological assumptions, which tends to socially associate men to greater technical skills and women to soft skills. 
Table 3. Survey participants profile.

\begin{tabular}{|c|c|c|c|c|}
\hline $\begin{array}{l}\text { Size of Company where } \\
\text { respondent works }\end{array}$ & Company Location & Position & Formation & Gender \\
\hline 27 "Big" 67.5\% & 3 international $7.5 \%$ & 13 Managers $32.5 \%$ & 27 Engineers $67.5 \%$ & 33 Men $82.5 \%$ \\
\hline 9 “Medium” 22.5\% & Among nationals-BR (100\%): & 8 Business Owners $20 \%$ & 8 Administrators $20 \%$ & 7 Women $17.5 \%$ \\
\hline \multirow[t]{8}{*}{4 “Small” $10 \%$} & 27 Santa Catarina $72.9 \%$ & 7 Directors (ou CEOs) $17.5 \%$ & 2 Accountants $5 \%$ & \\
\hline & & 3 Analysts $7.5 \%$ & 1 Geographist $2.5 \%$ & \\
\hline & & 3 Coordinators $7.5 \%$ & 1 Architect $2.5 \%$ & \\
\hline & & 2 Treasurer $5 \%$ & $1 \mathrm{Mec}$. technologist $2.5 \%$ & \\
\hline & & 2 Technical consultants & & \\
\hline & & $5 \%$ & & \\
\hline & & 1 Auditor $2.5 \%$ & & \\
\hline & & 1 Supervisor $2.5 \%$ & & \\
\hline
\end{tabular}

These figures raise a society trend to define and judge who has "normative social permission" to perform soft skills, but obviously both genders have and develop any type of them, whether from the hard or soft core.

Regarding the business profile of the organizations in which the interviewees work, most have the same family as owners of these companies. For Pimentel (2020), the main challenge in this company is the development of skills in its employees, since family members tend to be prioritized for management positions despite their abilities for the role. On the other hand, as they are family spaces, there is a bigger concern with maintaining the good image of the company and the family, including a greater requirement for ethics and management (Barreto et al., 2016).

Another analyzed factor concerns the position held, led $70 \%$ by owners, managers and directors of the organizations. For Zuo et al. (2018), the development of soft skills contributes significantly to the success factors of management in Engineering, justifying the high expectation that these groups of interviewees have of these competencies in their Engineering collaborators.

These employers of engineers also answered about their expectations for hiring a collaborator concerning soft skills, in addition to their perceptions about the reality in the job market, which were treated with fuzzy logic, as discussed in the next section.

\subsection{About Fuzzy and Collected Data}

The values of the responses to the questionnaires were used to calculate the average of each item, which, were then used as input data to the fuzzyTECH software, through which the data for each of the soft skills were considered relevant to the Engineering area were obtained.

Following are shown the groups of results, covering each of the soft skills of this study. 


\subsubsection{Results of the Soft Skill Critical Thinking}

In Table 4, the averages of the values displayed in the questionnaires are presented, for each of the guidelines that form the Soft Skills "Problem Solving" and "Open Mind", which in turn, after being treated, derive in the soft skill 'Critical Thinking'.

The values obtained in the item 'Critical Thinking' represent an unmet expectation in relation to the reality that is perceived by contractors in the Engineering area. The items referring to this soft skill (D1 \& D4) presented results well below the items related to the perceived reality in the market.

Regarding the development of this soft skill, one can think about the presence or absence of active methodologies in the academic field for Engineering. They are important in the development of critical thinking, as well as in the development of autonomy and in the discussion of the teaching process (Bazzo \& Pereira 2019).

Thus, it is necessary to reflect on methodologies, actions and practices in teaching and in the Engineering profession that promote reflections and critical sense, in order to make this soft skill increasingly present in Engineers, also in a reflective way towards the profession itself.

\subsubsection{Results of the Soft Skill Creative Thinking}

Table 5 summarizes the averages of the values assigned to the questionnaires, for each of the "Innovation" and "Creativity" guidelines, being input data from fuzzyTECH, which after being treated, structure the result of the "Creative Thinking" soft skill.

Regarding "Creative Thinking", the reality also showed a gap regarding to the expectations of the respondent employers. For Jankowska et al. (2018), Creative Thinking is a cognitive phenomenon that needs several factors for its manifestation, including multidisciplinary knowledge, idleness and the need for creation.

Table 4. Fuzzy data critical thinking.

\begin{tabular}{ccccccccc}
\hline & $\begin{array}{c}\text { D3-Ability to } \\
\text { solve problems in } \\
\text { a pacific manner }\end{array}$ & $\begin{array}{c}\text { D4-Openness to } \\
\text { suggestions, new ideas } \\
\text { and contrary options }\end{array}$ & Open Mind & $\begin{array}{c}\text { D1-Find solutions } \\
\text { using multidisciplinary } \\
\text { knowledge }\end{array}$ & $\begin{array}{c}\text { D2-Use knowledge, } \\
\text { data and facts to solve } \\
\text { problems at work }\end{array}$ & $\begin{array}{c}\text { Problem } \\
\text { Solving }\end{array}$ & $\begin{array}{c}\text { Critical } \\
\text { Thinking }\end{array}$ \\
\hline & \multicolumn{2}{c}{ Entry Data } & fuzzy & & Entry Data & & fuzzy & fuzzy \\
\hline $\begin{array}{l}\text { expectation } \\
\text { reality }\end{array}$ & 6.5 & 6.5 & 9.14 & 8.5 & 6.5 & 9.17 & 9.17 \\
\hline
\end{tabular}

Source: Campos, 2019.

Table 5. Fuzzy data creative thinking.

\begin{tabular}{cccc}
\hline & Creativity & Innovation & Creative Thinking \\
\hline Entry Data & Entry Data & fuzzy \\
\hline expectation & 7.5 & 7.5 & $\mathbf{8 . 3 3}$ \\
reality & 6.5 & 6.5 & 6.65 \\
\hline
\end{tabular}

Source: Campos, 2019. 
Engineering tends to be associated to a more dogmatic rather than innovative field, starting from teaching at universities (Bazzo \& Pereira, 2019), which highlights the importance of implementing innovative ideas within universities, in order to promote further practical development of this soft skill. It also suggests the need to rethink the excessive workload in the Engineering area, as leisure and idleness directly influence the development of Creative Thinking (Sergeyeva et al. 2019).

Thus, it is possible to understand the great importance of Creative Thinking and the necessity of developing it in the teaching and practice of Engineering, as it is an area focused on the creation processes.

\subsubsection{Results of the Soft Skill Communication}

Table 6 presents the results for "Foreign Language" and "Reading" guidelines, which values were obtained from the averages of the responses to the questionnaires, and then used as input data in fuzzyTECH. In addition, the averages of the values granted to the questionnaires are also shown, each one of the guidelines that integrate the "Active Listening", "Orality" and "Writing" soft skill, which together with the "Foreign Language" and "Reading" guidelines were treated, producing the result of the soft skill "Communication".

In the sub-item "Orality" of the soft skill "Communication", the expectation values are in equivalent proportion when compared to the reality perceived in the labor market scenario. However, in the other sub-items already treated through fuzzy logic, the indexes fell below the values expected by employers, showing a numerical deficit.

For Bodnar \& Clark, 2017, Engineering graduates do not have enough oral and writing communication for the market's needs, which influences their employment even in purely industrial practices.

In order to better develop the professionals graduated every year in Engineering universities in the most diverse areas of activity, the importance and the need to provoke methods and reflections on communicative processes needs to be considered, deconstructing the idea that the sciences in the STEM field are

Table 6. Fuzzy data communication.
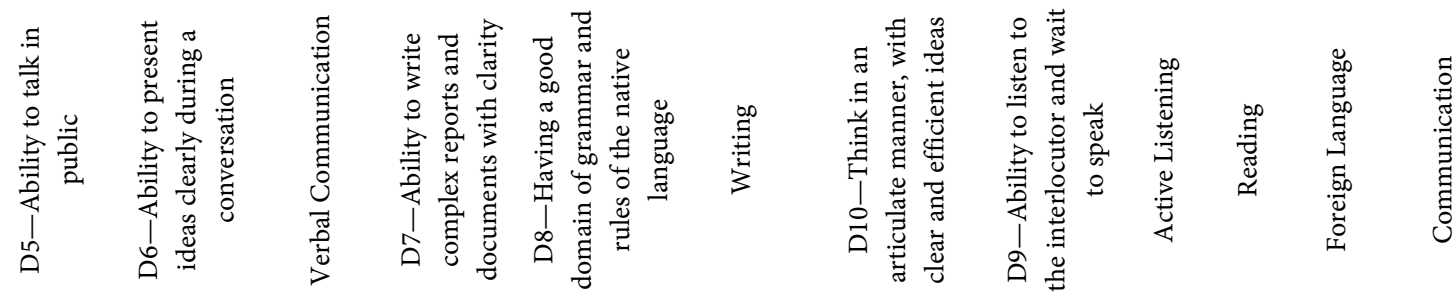

\begin{tabular}{|c|c|c|c|c|c|c|c|c|c|c|c|}
\hline \multirow[b]{2}{*}{ expectation } & \multicolumn{2}{|c|}{ Entry Data } & \multirow{2}{*}{$\begin{array}{c}\text { fuzzy } \\
8.4\end{array}$} & \multicolumn{2}{|c|}{ Entry Data } & \multirow{2}{*}{$\begin{array}{c}\text { fuzzy } \\
8.3\end{array}$} & \multicolumn{2}{|c|}{ Entry Data } & \multirow{2}{*}{$\begin{array}{c}\text { fuzzy } \\
7.0\end{array}$} & \multirow{2}{*}{$\begin{array}{r}\text { Entry Data } \\
8.5\end{array}$} & \multirow{2}{*}{$\begin{array}{c}\text { fuzzy } \\
7.9\end{array}$} \\
\hline & 7.0 & 7.5 & & 7.5 & 7.5 & & 7.0 & 5.5 & & & \\
\hline reality & 7.5 & 8.0 & 9.0 & 4.0 & 5.5 & 4.3 & 5.0 & 5.0 & 5.0 & 6.5 & 5.9 \\
\hline
\end{tabular}

Source: Campos, 2019. 
isolated from the humanities.

\subsubsection{Results of the Soft Skill Team Work}

Table 7 presents the results for "Contact Network" and "Multiculturality" guidelines, which values were obtained from the average of the responses to the questionnaires, then used as input data in fuzzyTECH. It also shows the averages of the values displayed in the questionnaires for each of the guidelines that make up the soft skill "Leadership", together with the "Contact Network" and "Multiculturality" guidelines, which, after being treated through fuzzy logic, resulted in the soft skill “Team Work".

The expectation values compared to the reality perceived in the job market by Engineering employers are relatively equivalent, with little dissonance. It is interesting to notice that the results suggest a relatively low need of the employer for this soft skill, especially considering the fact that it is common to have work group in organizations.

For Ribeiro, Cartaxo, \& Silva (2019), Agreli, Peduzzi, \& Bailey (2017) due to the Team Work showing itself in the group, there is usually room for compensation among the team members regarding the challenges of the Engineering profession.

With this soft skill, there is a greater perspective of multiculturalism, diversity, helping to create an environment that favors the perception of managers about the strengths of all members of the group.

\subsubsection{Results of the Soft Skill Ethical Perspective}

Table 8 shows the averages of the values displayed in the questionnaires, for

Table 7. Fuzzy data team work.

\begin{tabular}{|c|c|c|c|c|c|c|c|}
\hline & 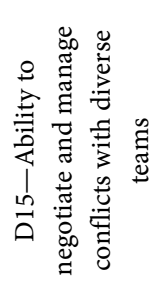 & 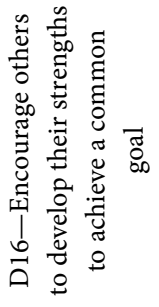 & 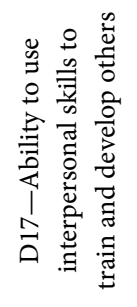 & 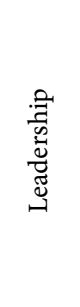 & 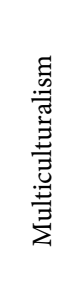 & 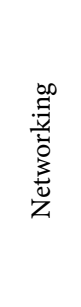 & 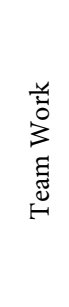 \\
\hline & & Entry Data & & fuzzy & $\begin{array}{l}\text { Entry } \\
\text { Data }\end{array}$ & $\begin{array}{l}\text { Entry } \\
\text { Data }\end{array}$ & fuzzy \\
\hline expectation & 6.5 & 6.0 & 7.0 & 6.5 & 7.0 & 5.5 & 6.53 \\
\hline reality & 6.0 & 5.0 & 5.0 & 5.0 & 4.5 & 8.0 & 6.33 \\
\hline
\end{tabular}

Source: Campos, 2019.

Table 8. Fuzzy data ethical perspective.

\begin{tabular}{ccccc}
\hline & Ethics & Professionalism & Social Responsibility & Ethical Perspective \\
\cline { 2 - 5 } & Entry Data & Entry Data & Entry Data & fuzzy \\
\hline expectation & 9.0 & 8.0 & 6.5 & $\mathbf{8 . 9 6}$ \\
reality & 8.5 & 8.0 & 5.5 & $\mathbf{7 . 0 1}$ \\
\hline
\end{tabular}

Source: Campos, 2019. 
each of the "Social Responsibility", "Professionalism" and "Ethics" guidelines, which were input data from fuzzyTECH and which after treated by fuzzy logic, composed the result of soft skill "Ethical Perspective".

Based on the data, it is observed that the reality presented by the professionals is still deficient compared to the expectation of the employers. On the other hand, there is an increasing direction of society's actions in favor of ethics, making this soft skill an essential value to the professional practice.

The main objective of ethics in Engineering practice is the consolidation of the decision making in accordance with the codes of ethics already established in organizations and also considering the society perspective (Beever \& Brightman 2016).

In order to maintain an ethical and professional attitude in Engineering practice, based on this soft skill, the professional is able to promote self-regulation and manage their own values.

\subsubsection{Results of the Soft Skill Emotional Intelligence}

Table 9 shows the guidelines Self-direction and Lifelong Learning (represented by the letter "D"), which values were reached from the average results of the questionnaires, used as input data in fuzzyTECH. The averages of the values attributed to the questionnaires are also characterizes, to each of the guidelines that integrate the soft skills "Control of Emotions" and "Motivation", which, together with the guidelines "Lifelong Learning" and "Self-Direction", result in the soft skill e "Emotional Intelligence".

The results of the perception of the contractors related to "Emotional Intelligence" showed higher rates when compared to the expectation of the market. One explanation for this result is supported by the fact that most respondents (67.5\%) are Engineers, and they may not be able to perceive the practical need for this skill.

There are already studies supporting that Emotional Intelligence is suggested as the most necessary of all other intelligences (Rocha 2016). For Fair et al. 2005, it can be developed throughout life, different from the intelligence coefficient,

Table 9. Fuzzy data emotional intelligence.

\begin{tabular}{|c|c|c|c|c|c|c|c|c|c|c|}
\hline & 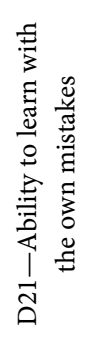 & 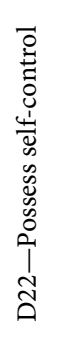 & 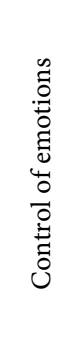 & 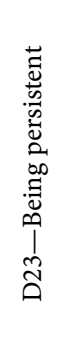 & 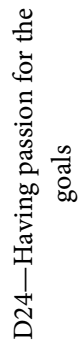 & 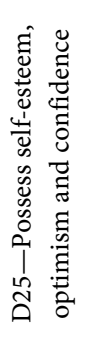 & 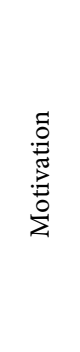 & 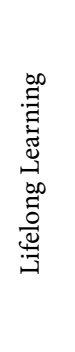 & 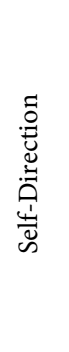 & 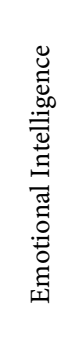 \\
\hline & \multicolumn{2}{|c|}{ Entry Data } & fuzzy & \multicolumn{3}{|c|}{ Entry Data } & fuzzy & Entry & Data & fuzzy \\
\hline expectation & 6.5 & 6.5 & 6.647 & 7.0 & 8.0 & 6.5 & 6.805 & 8.5 & 7.5 & 6.83 \\
\hline reality & 7.0 & 6.0 & 6.805 & 7.50 & 7.5 & 7.5 & 7.916 & 7.5 & 6.5 & 7.68 \\
\hline
\end{tabular}

Source: Campos, 2019. 
which remains static.

Control of emotions, focus on objectives and personal interest in lifelong learning are characteristics of this skill, necessary for the maintenance of a harmonious space that enables the well-being of Engineering professionals.

\subsubsection{Summary of the Results of the Soft Skills}

Table 10 presents the values obtained through the fuzzy analysis of all the guidelines, culminating in the results of the soft skills "Team Work", "Communication", "Critical Thinking", "Creative Thinking", "Emotional Intelligence" and "Ethical Perspective", which after treated by fuzzy logic originated the result of soft skills, both according to the expectations of employers regarding the level of these soft skills in Engineers and to their perceptions in the real scenario, based on their Engineers collaborators.

The results of the expectation of employers in the Engineering area are far above the reality observed in the labor market, showing that there is an urging need for the development of soft skills in Engineers.

Nusrat \& Sultana 2019 endorse this perception that there are insufficient soft skills. Through their studies on the expectations of the job market, they have found that there is a clear gap from what executives expect from both graduates and fresh graduates. They also state that having these skills developed at university would favor the employability of Engineers.

Therefore, universities need to put efforts to at least highlight the importance of humanities and soft skills, even in the practice of sciences related to the STEM field. Thus, in case there is no possibility to work and develop them diligently during the course, the student understands its importance and seeks to improve them independently.

\section{Conclusion}

From the data collected and discussions developed throughout this study, it is possible to conclude that the objectives were met when evaluating the expectation and perception of the reality by 40 participants engineering employers, in relation to soft skills.

Table 10. Results summary.

\begin{tabular}{|c|c|c|c|c|c|c|c|}
\hline & 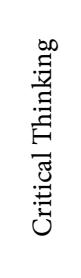 & 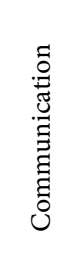 & 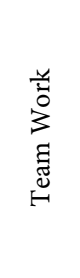 & 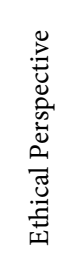 & 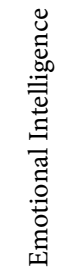 & 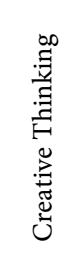 & 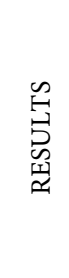 \\
\hline & fuzzy & fuzzy & fuzzy & fuzzy & fuzzy & fuzzy & fuzzy \\
\hline expectation & 9.17 & 7.92 & 6.53 & 8.96 & 6.83 & 8.33 & 9.17 \\
\hline reality & 6.64 & 5.89 & 6.33 & 7.01 & 7.68 & 6.65 & 6.78 \\
\hline
\end{tabular}

Source: Campos, 2019. 
This study firstly showed the importance of soft skills to Engineering professionals, reflecting positively in relation to professional performance, employability and permanence on their jobs.

The skills addressed in this research come from several areas such as Linguistics, Philosophy and Applied Social Sciences and were systematized here in major groups important for training in engineering: Critical Thinking, Creative Thinking, Communication, Team Work, Ethical Perspective and Emotional Intelligence. These trans/multi and interdisciplinary inherent to soft skills are presented in order to complete the training of an Engineer, demonstrating that only technical skills are not sufficient for the comprehensive training of this professional for the job market.

The results show that the Engineering employers have an unmet expectation with regard to soft skills in the labor market in all these above mentioned groups, except the Emotional Intelligence skill. This study does not propose an extensive list of solutions for this disparity between expectation and reality, but the results give rise to reflections on whether the manner, quantity and quality of the development of soft skills in Engineering courses are congruent and sufficient with the current employers' demand.

One recommendation to reduce the gap between the expectation and the reality perceived by employers is the massive and active participation of the academy in the formation of the soft skills of the Engineer. Through the use of active methodologies and integrating projects, which have interdisciplinary teaching as a strategy, meeting the report "Comparative study on the curricula of Engineering courses in Brazil and Europe and suggestions for fostering innovation" (Diálogos Setoriais, 2017), it is possible to create an environment which provides and facilitates the development of soft skills. The integrative projects, in the Engineering courses, provide an opportunity for the development and practice of skills, such as teamwork, communication, leadership, management, professionalism, creative thinking and theoretical application of the technique.

Hence, it is indispensable that the academic community focuses on continuous development to attend job market's demands, since the development of soft skills has to start in the academia, and further developed through professional and life experiences and reflected in the human relationships that the professional establishes.

\section{Conflicts of Interest}

The authors declare no conflicts of interest regarding the publication of this paper.

\section{References}

Abenge-Associação Brasileira de Educação em Engenharia (2020). Proposta de diretrizes curriculares nacionais para o curso de engenharia. http://www.abenge.org.br/

Agreli, H. F., Peduzzi, M., \& Bailey, C. (2017). The Relationship between Team Climate and Interprofessional Collaboration: Preliminary Results of a Mixed Methods Study. 
Journal of Interprofessional Care, 31, 184-186.

https://doi.org/10.1080/13561820.2016.1261098

Barreto, L. K. S., Leone, N. M. C. G. P., \& Angeloni, M. T. (2016). Competências gerenciais requeridas em empresas familiares: $\mathrm{O}$ olhar de sucessores. $R A C E-$ Revista de Administração, Contabilidade e Economia, 15, 299-326.

https://doi.org/10.18593/race.v15i1.9128

Belohlávek, R., Dauben, J., \& Klir, G. (2017). Fuzzy Logic and Mathematics: A Historical Perspective. New York: Oxford University Press. https://doi.org/10.1093/oso/9780190200015.001.0001

Bodnar, C. A., \& Clark, R. M. (2017). Can Game-Based Learning Enhance Engineering Communication Skills? IEEE Transactions on Professional Communication, 60, 24-41. https://doi.org/10.1109/TPC.2016.2632838

Boff, L. (2017). Saber cuidar: Ética do humano-compaixão pela Terra (302 p.). Petrópolis: Vozes.

Campos, D. B. (2019). Desenvolvimento de um Modelo Diagnóstico de Formação de Competências Socioemocionais para Cursos de Engenharia. 2019. 222 f. Tese (Doutorado)-Curso de Ensino de Ciência e Tecnologia, Pós-graduação em Ensino de Ciência e Tecnologia, Universidade Tecnológica Federal do Paraná, Ponta Grossa.

Campos, D. B., De Resende, L. M. M., \& Fagundes, A. B. (2020). The Importance of Soft Skills for the Engineering. Creative Education, 11, 1504-1520.

https://doi.org/10.4236/ce.2020.118109

Carbone, P. P., Brandão, H. P., \& Leite, J. B. D. (2005). Gestão por competências e gestão do conhecimento (172 p.). Rio de Janeiro: Fundação Getúlio Vargas.

Diálogos Setoriais União Europeia-Brasil. Estudo comparado sobre os currículos dos cursos de engenharia no Brasil e na Europa e sugestões para o fomento à inovação (2017). Ministério da Indústria, Comércio Exterior e Serviço e Ministério do Planejamento, Desenvolvimento e Gestão.

http://www.sectordialogues.org/sites/default/files/publicacao educ-30mar-web-final.pdf

El Mansour, B., \& Dean, J. C. (2016). Employability Skills as Perceived by Employers and University Faculty in the Fields of Human Resource Development (HRD) for Entry Level Graduate Jobs. Journal of Human Resource and Sustainability Studies, 4, 39. https://doi.org/10.4236/jhrss.2016.41005

Gil, A. C. (2002). Como elaborar projetos de pesquisa (Vol. 4, p. 175). São Paulo: Atlas.

Hasanah, M., \& Surya, E. (2017). Differences in the Abilities of Creative Thinking and Problem Solving of Students in Mathematics by Using Cooperative Learning and Learning of Problem Solving. IJSBAR, 34, 286-299.

Hong, R. (2016). Soft Skills and Hard Numbers: Gender Discourse in Human Resources. Big Data \& Society, 3, 1-13. https://doi.org/10.1177/2053951716674237

Itani, M., \& Srour, I. (2015). Engineering Students' Perceptions of Soft Skills, Industry Expectations, and Career Aspirations. Journal of Professional Issues in Engineering Education and Practice, 142, Article ID: 04015005. https://doi.org/10.1061/(ASCE)EI.1943-5541.0000247

Jankowska, D. M., Czerwonka, M., Lebuda, I., \& Karwowski, M. (2018). Exploring the Creative Process: Integrating Psychometric and Eye-Tracking Approaches. Frontiers in Psychology, 9, 1931. https://doi.org/10.3389/fpsyg.2018.01931

Laranjeiro, A. C., Suleman, F., \& Botelho, M. C. A. (2020). Empregabilidade dos Graduados: Competências procuradas nos anúncios de emprego. Sociologia, Problemas e Práticas, 93, 49-69. https://doi.org/10.7458/SPP20209312055 
Listone, H. A., \& Turoff, M. (2002). The Delphi Method: Techniques and Applications, College of Computing Sciences (618 p.). Newark, NJ: New Jersey Institute of Technology.

Nascimento, J. H. F. C. (2019). Desenvolvimento de competências comportamentais em equipes de atendimento ao cliente em empresa de tecnologia. 2019. 32 f. Monografia (Especialização)—Curso de Gestão de Pessoas, Universidade do Vale do Rio dos Sinos, Porto Alegre: Unisinos.

OECD (2016). The Survey of Adult Skills: Reader's Companion (2nd ed.). OECD Skills Studies, Paris: OECD Publishing.

Paul, R., \& Elder, L. (2020). Critical Thinking: Concepts and Tools (48 p.). Lanham, MD: Rowan and Littlefield.

Pellegrini, A. M. (2017). A aprendizagem de habilidades motoras I: O que muda com a prática? Revista Paulista de Educação Física, 3, 29-34.

Pimentel, D. (2020). Empresas Familiares: Desafios à Gestão do Capital Humano (pp. 1-7). https://doi.org/10.31234/osf.io/s7kjg

Ramadi, E., Ramadi, S., \& Nasr, K. (2015). Engineering Graduates' Skill Sets in the MENA Region: A Gap Analysis of Industry Expectations and Satisfaction. European Journal of Engineering Education, 41, 34-52. https://doi.org/10.1080/03043797.2015.1012707

Reh, F. J. (2020). The Role and Responsibilities of a Manager: Take a Look at the Role and Responsibilities of Today's Manager. Take a Look at the Role and Responsibilities of Today's Manager. https://www.thebalancecareers.com/what-is-a-manager-2276096

Ribeiro, D. M., Cartaxo, D. A. B., \& Silva, F. Q. B. (2019). Explorando o conhecimento da equipe em engenharia de software: Um estudo de caso múltiplo. iSys, 12, 117-150. https://doi.org/10.5753/isys.2019.783

Rios-Carmenado, I., Rodríguez, F., \& García, C. (2015). Promoting Professional Project Management Skills in Engineering Higher Education: Project-Based Learning (PBL) Strategy. International Journal of Engineering Education, 31, 1-15.

Schipper, M., \& van der Stappen, E. (2018). Motivation and Attitude of Computer Engineering Students toward Soft Skills. 2018 IEEE Global Engineering Education Conference (EDUCON), Tenerife, 17-20 April 2018, 217-222. https://doi.org/10.1109/EDUCON.2018.8363231

Serrat, O. (2017). Understanding and Developing Emotional Intelligence. In Knowledge Solutions (pp. 329-339). Singapore: Springer. https://doi.org/10.1007/978-981-10-0983-9 37

Swiatkiewicz, O. (2014). Soft, Hard, or Moral Skills: An Exploratory Study on the Workers' Skills That Organizations in Portugal Appreciate Most. Cadernos EBAPE.BR, 12, 633-687. https://doi.org/10.1590/1679-395112337

Tibério, J. R., \& Tonini, A. M. (2013). The Role of the Engineer as a Manager: Relations and Professional Knowledge in Practice. Trabalho \& Educação, 22, 143-152.

Zuo, J., Zhao, X., Nguyen, Q. B. M., Ma, T., \& Gao, S. (2018). Soft Skills of Construction Project Management Professionals and Project Success Factors: A Structural Equation Model. Engineering, Construction and Architectural Management, 25, 425-442. https://doi.org/10.1108/ECAM-01-2016-0016 